\title{
An $\alpha$-Amylase Inhibitor from Cranberry Bean (Phaseolus vulgaris): Its Specificity in Inhibition of Mammalian Pancreatic $\alpha$-Amylases and Formation of a Complex with the Porcine Enzyme
}

\author{
Makoto Kotaru, Hideki Yoshikawa, Tsuneo IKEUCHI, ${ }^{1}$ \\ Koichi SAITo, Kimikazu IWAMI, and Fumio IBUKI ${ }^{2}$ \\ ${ }^{1}$ Department of Home Economics, Koka Women's Junior College, \\ Ukyo-ku, Kyoto 615, Japan \\ ${ }^{2}$ Department of Agricultural Chemistry, Faculty of Agriculture, \\ Kyoto Prefectural University, Sakyo-ku, Kyoto 606, Japan
}

(Received May 18, 1987)

\begin{abstract}
Summary A proteinaceous inhibitor that inhibits mammalian $\alpha$-amylases was prepared from cranberry bean and examined for its reactivity with $\alpha$-amylases from various origins. The cranberry bean $\alpha$-amylase inhibitor (CBAI) exhibited inhibitory effects on pancreatic $\alpha$-amylases from the following mammals: pig, dog, cat, horse, sheep, cow, rabbit, guinea pig, rat, and mouse. CBAI showed a maximal inhibition at $\mathrm{pH} 5.5$ against porcine pancreatic $\alpha$-amylase (PPA). It was confirmed by gel filtration that a complex was formed in the 1:1 ratio between CBAI and PPA when they were incubated at $37^{\circ} \mathrm{C}$ for $30 \mathrm{~min}$ at $\mathrm{pH} \mathrm{5.5.} \mathrm{A} \mathrm{similar}$ inhibition pattern was also observed at $\mathrm{pH} 6.9$ that is optimal for the amylase reaction, but much higher concentrations of CBAI were required to give $50 \%$ inhibition at $\mathrm{pH} 6: 9$ than at $\mathrm{pH} 5.5$. Especially, both bovine and rat $\alpha$-amylases were virtually unreactive to CBAI at $\mathrm{pH} 6.9$.
\end{abstract}

Key Words formation of complex, species-specificity, $\alpha$-amylase inhibitor, pancreatic $\alpha$-amylase, cranberry bean

Proteinaceous $\alpha$-amylase inhibitors have been found in cereals $(1-4)$, legumes $(5-8)$, tubers $(9,10)$, and bacteria (11) and characterized by the specificity towards animal $\alpha$-amylases. Although the mechanism of inhibition is still obscure, the inhibitors are practically applicable to the control of post-prandial glucose level in the blood by disturbing digestion of starch in the intestine (12) and to the purification of salivary or pancreatic $\alpha$-amylase by using as adsorbent for affinity chromatography (13). In a previous paper (14), we have reported the isolation of an amylase inhibitor from cranberry bean (Phaseolus vulgaris) (CBAI), and its

1 小垂 真, 吉川秀樹, 池内常郎, ${ }^{2}$ 斎藤晃一, 岩見公和, 伊吹文男 
physicochemical properties. The inhibitor was a glycoprotein, which acted effectively on porcine pancreatic $\alpha$-amylase (PPA).

The present paper deals with the formation of a complex between CBAI and PPA and with the inhibition spectrum of CBAI against pancreatic $\alpha$-amylase from various animals.

\section{MATERIALS AND METHODS}

Materials. CBAI was purified as previously described (14). Porcine pancreatic and human salivary $\alpha$-amylases and amylases from Aspergillus oryzae, Bacillus subtilis, barley malt, and sweet potato were purchased from Sigma Chemical Co. Pancreas from pig, dog, cat, horse, sheep, cow, rabbit, guinea pig, rat, and mouse were also obtained as acetone powder from Sigma Chemical Co., from which $\alpha$ amylases were purified in our laboratory by affinity chromatography with potato starch according to the method described by Tsujisaka (15). Other chemicals of analytical grade were commercially available and used without further purification.

Protein determination and molarity calculation. Protein was determined by the method of Lowry et al. (16) using bovine serum albumin as standard. The molar concentrations of PPA and CBAI were calculated on the basis of their molecular weights of 54,000(17) and 45,000(14), respectively.

Enzyme assay. The $\alpha$-amylase activity was measured by a modification of the iodine method by Murao et al. (18). The reaction mixture containing an appropriate concentration of $\alpha$-amylase, $0.5 \%$ soluble starch, $50 \mathrm{~mm} \mathrm{NaCl}, 5 \mathrm{~mm} \mathrm{CaCl}_{2}$ and $0.01 \%$ ovalbumin in $20 \mathrm{~mm}$ piperazine- $N, N^{\prime}$-bis(2-ethanesulfonic acid) (PIPES) buffer ( $\mathrm{pH}$ 6.9) was incubated at $37^{\circ} \mathrm{C}$ for $10 \mathrm{~min}$. The reaction was stopped by adding $2.5 \mathrm{ml}$ of an acidic solution containing $0.08 \mathrm{M} \mathrm{HCl}$ and $0.4 \mathrm{M}$ acetic acid to $1.5 \mathrm{ml}$ of the reaction mixture. To its aliquot $(0.4 \mathrm{ml}), 5 \mathrm{ml}$ of an aqueous solution containing $0.005 \%$ iodine and $0.05 \%$ potassium iodine was added to measure the absorbance at $660 \mathrm{~nm}$. One unit of enzyme was defined as the amount of enzyme capable of producing 0.8 decrease in the absorbance.

$p H$ Dependence of inhibition by CBAI. A unit of PPA was incubated at $37^{\circ} \mathrm{C}$ for 30 min together with $1.2 \times 10^{-8} \mathrm{M} \mathrm{CBAI}$ in various buffers composed of $10 \mathrm{~mm}$ sodium citrate $(\mathrm{pH} 4.0-5.5)$ or $10 \mathrm{~mm}$ sodium phosphate $(\mathrm{pH} 6.0-8.0)$ and $40 \mathrm{~mm}$ $\mathrm{NaCl}$ and $2 \mathrm{mM} \mathrm{CaCl}_{2}$. The residual $\alpha$-amylase activity after the indicated incubation period was measured as mentioned above, and the extent of inhibition was expressed in percentage as the difference between the activities in the presence and absence of CBAI under the assay conditions.

Gel filtration. A mixture of PPA at $1.8 \times 10^{-5} \mathrm{M}$ and CBAI at $9.2 \times 10^{-6} \mathrm{M}$ in $50 \mathrm{~mm}$ acetate buffer ( $\mathrm{pH} 5.5$ ) containing $50 \mathrm{~mm} \mathrm{NaCl}$ and $5 \mathrm{mM} \mathrm{CaCl}_{2}$ that had been incubated at $37^{\circ} \mathrm{C}$ for $60 \mathrm{~min}$ was applied to a Toyo-Pearl HW-55 column $(2.6 \phi \times 95 \mathrm{~cm})$ previously equilibrated with the same buffer, and the effluents were fractionated in each $4.0 \mathrm{ml}$. Aliquots $(0.01 \mathrm{ml})$ of the fractions were assayed for their amylase and inhibitor activities. 
Stoichiometry in formation of a complex. For the purpose of stoichiometric investigation on the formation of a complex between PPA and CBAI, a mixture of PPA at a fixed level $\left(1.6 \times 10^{-8} \mathrm{M}\right)$ and CBAI at two fixed levels $\left(6.5 \times 10^{-9} \mathrm{M}\right.$ and $\left.1.3 \times 10^{-8} \mathrm{M}\right)$ was incubated at $\mathrm{pH} 5.5$ and $37^{\circ} \mathrm{C}$ and its aliquots $(1.0 \mathrm{ml})$ were withdrawn at stated intervals during incubation to measure the residual $\alpha$-amylase activity. Subsequently, PPA $\left(1.6 \times 10^{-8} \mathrm{M}\right)$ was incubated at $\mathrm{pH} 5.5$ and $37^{\circ} \mathrm{C}$ for $60 \mathrm{~min}$ together with $\mathrm{CBAI}$ at varied concentrations of $1.4 \times 10^{-9} \mathrm{M}$ to $1.4 \times 10^{-8} \mathrm{M}$, and then, the residual $\alpha$-amylase activity was likewise measured.

Reactivity of CBAI with various amylases. CBAI $\left(1.2 \times 10^{-7} \mathrm{M}\right)$ was allowed to act on amylases from various sources such as animal, plant, fungus, and bacteria in $50 \mathrm{~mm}$ acetate buffer $(\mathrm{pH} 5.5)$ or in $20 \mathrm{~mm}$ PIPES buffer $(\mathrm{pH} 6.9)$ at $37^{\circ} \mathrm{C}$ for $30 \mathrm{~min}$. The residual amylase activity was measured at $\mathrm{pH} 6.9$ with $\alpha$-amylases from animals and at pH 5.5 with amylases from other sources. The specificity of CBAI towards pancreatic $\alpha$-amylases was investigated using the acetate buffer ( $\mathrm{pH} 5.5$ ) and the PIPES buffer ( $\mathrm{pH}$ 6.9), in which both incubation and activity measurement were carried out.

\section{RESULTS AND DISCUSSION}

A unit of PPA underwent $25 \%$ inhibition of the initial activity after incubation of $30 \mathrm{~min}$ at $25^{\circ} \mathrm{C}$ and $\mathrm{pH} 6.9$ in the presence of $6.2 \times 10^{-8} \mathrm{M}$ CBAI. The degree of inhibition by CBAI increased with increasing temperature, and the preincubation at $40^{\circ} \mathrm{C}$ caused a threefold increase in inhibition relative to that at $25^{\circ} \mathrm{C}$. In this connection, Marshall and Lauda (5) and Powers and Whitaker (19) have referred to

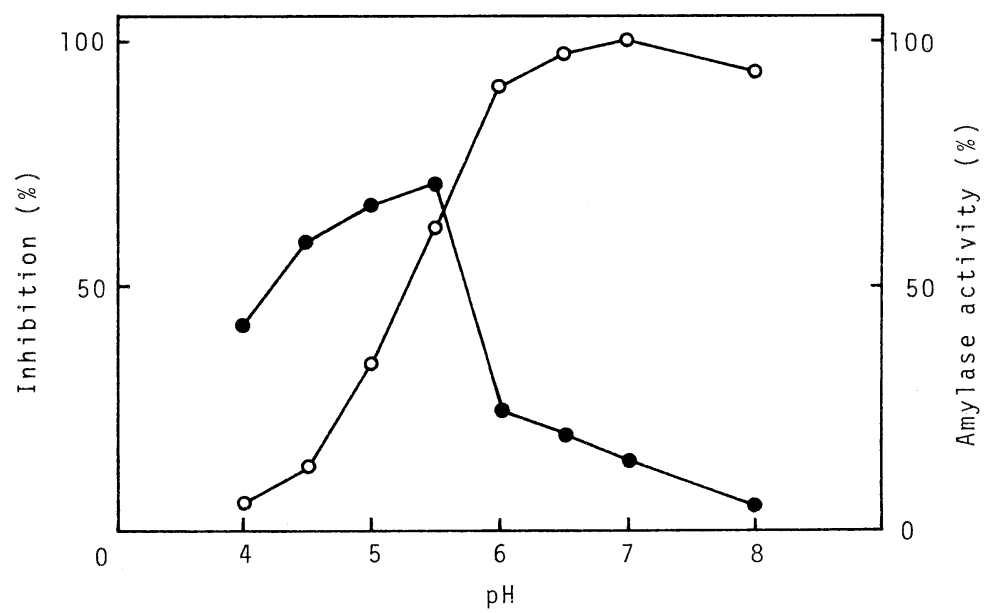

Fig. 1. Effects of $\mathrm{pH}$ on inhibition of PPA by CBAI. PPA was incubated at various pHs with CBAI for $30 \mathrm{~min}$ at $37^{\circ} \mathrm{C}$. Controls were run without inhibitor at each $\mathrm{pH}$ simultaneously $(\bigcirc)$. The extent of inhibiton $(\bullet)$ at different $\mathrm{pHs}$ was calculated by setting $\alpha$-amylase activity in each control incubation at $100 \%$. 


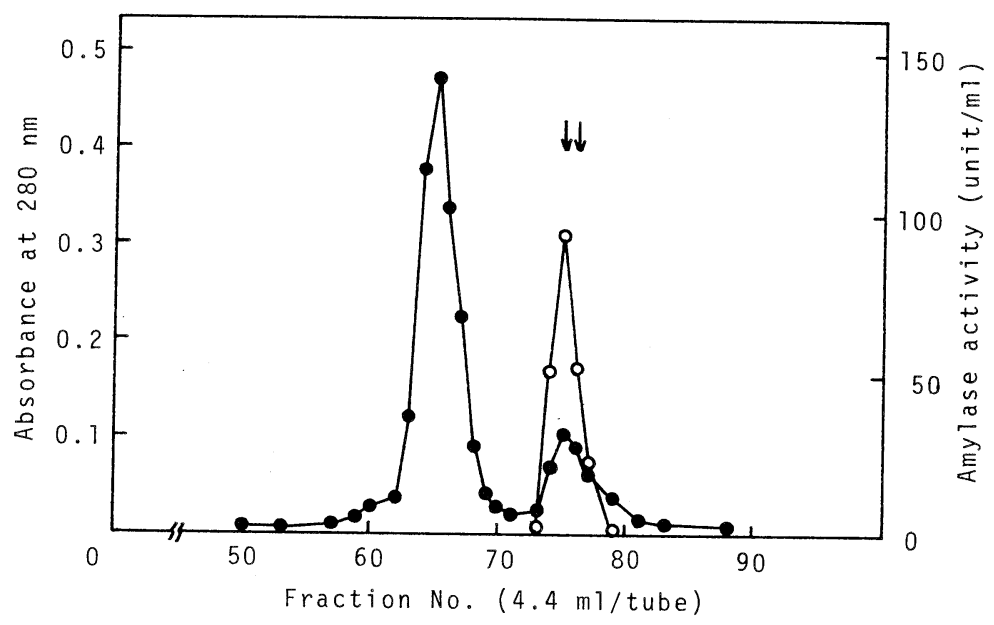

Fig. 2. Gel filtration of the mixture of PPA and CBAI. PPA and CBAI were incubated in $50 \mathrm{~mm}$ acetate buffer ( $\mathrm{pH}$ 5.5) containing $50 \mathrm{mM} \mathrm{NaCl}$ and $5 \mathrm{mM} \mathrm{CaCl}_{2}$ for $60 \mathrm{~min}$ at $37^{\circ} \mathrm{C}$. The mixture was applied to a Toyo-Pearl HW-55 column $(2.6 \phi \times 95 \mathrm{~cm})$ and then eluted with the same buffer. Left and right arrows indicate where free PPA and CBAI were eluted, respectively. Amylase activity (O), absorbance at $280 \mathrm{~nm}$ $(\bullet)$.

the more rapid formation of a complex between PPA and kidney bean $\alpha$-amylase inhibitor at $25^{\circ} \mathrm{C}$ than at $37^{\circ} \mathrm{C}$, while Buonocore et al. (20) have found that there is a decrease in inhibition of chicken pancreatic $\alpha$-amylase by wheat kernel inhibitors at above $30^{\circ} \mathrm{C}$. Nevertheless incubation was carried out at $37^{\circ} \mathrm{C}$ in our experiment.

Figure 1 shows the effects of $\mathrm{pH}$ on inhibition of PPA by CBAI; CBAI exhibited the highest inhibitory effect on PPA at $\mathrm{pH}$ 5.5. The drop in inhibition below or above $\mathrm{pH} 5.5$ was considered not due to denaturation of CBAI, because the inhibitor was stable over the $\mathrm{pH}$ ranges of 3 to $7(21)$. The optimum $\mathrm{pH}$ of inhibition against PPA was in the range of 4.5 to 5.5 with $\alpha$-amylase inhibitors from many beans $(5,22)$, while wheat inhibitors were most inhibitory at $\mathrm{pH} \mathrm{6.4-8.4} \mathrm{and}$ pH 5.8-7.0 against human salivary and pancreatic $\alpha$-amylases, respectively (l).

Figure 2 shows a typical gel filtration pattern of the CBAI and PPA mixture that had been previously incubated under the conditions optimal for inhibition. In the presence of $\alpha$-amylase excess to inhibitor, two peaks appeared on the chromatogram. Neither $\alpha$-amylase nor inhibitor activities were detected in the first peak. Taking into account the elution volume, there is little doubt that the first peak component is responsible for a complex formed between PPA and CBAI. Tanizaki and Lajolo (23) have reported that the complex between PPA and kidney bean $\alpha$ amylase inhibitor is partially dissociative at acidic $\mathrm{pH}$ or above $\mathrm{pH}$ 6.5. On either side of the optimum $\mathrm{pH}$, a similar dissociation may have occurred in the complex between PPA and CBAI. The second peak component was attributable mainly to PPA by activity measurement. 


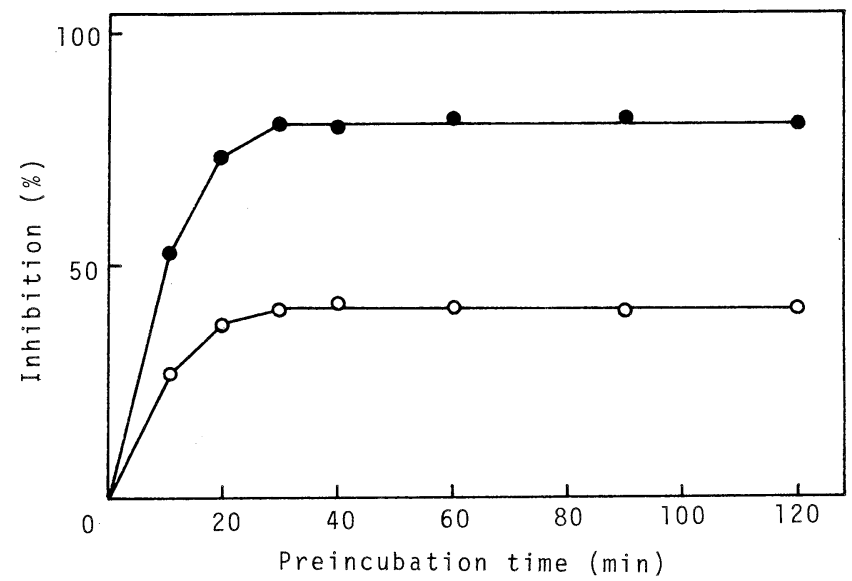

Fig. 3. Time course of inhibition of PPA by CBAI. PPA $\left(1.6 \times 10^{-8} \mathrm{M}\right)$ was incubated with two different levels of CBAI at $\mathrm{pH} 5.5$ and $37^{\circ} \mathrm{C}$, respectively. After varying times of incubation, residual $\alpha$-amylase activity was determined. $6.5 \times 10^{-9} \mathrm{M}$ of CBAI (O), $1.3 \times 10^{-8} \mathrm{M}$ of CBAI (๑).

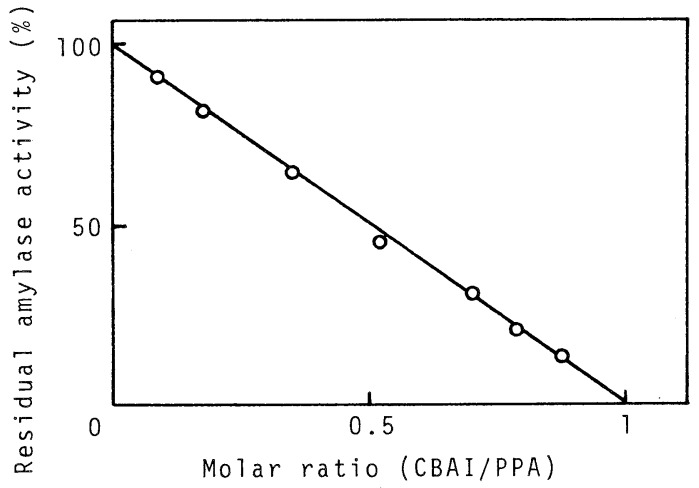

Fig. 4. Stoichiometry of inhibition of PPA by CBAI. PPA $\left(1.6 \times 10^{-8} \mathrm{M}\right)$ was incubated at $\mathrm{pH} 5.5$ and $37^{\circ} \mathrm{C}$ for $60 \mathrm{~min}$ with $\mathrm{CBAI}$ at varied concentrations of $1.4 \times 10^{-9} \mathrm{M}$ to $1.4 \times 10^{-8} \mathrm{M}$, and then, the residual $\alpha$-amylase activity was measured.

Figure 3 shows the time course of inhibition of PPA at a fixed level by CBAI at two fixed levels. The complete inhibition took place in $30 \mathrm{~min}$ at $\mathrm{pH}$ 5.5. However, the inhibition was not completed at $\mathrm{pH} 6.9$ even after incubation of $6 \mathrm{~h}$ (data not shown). In this regard, it took $1 \mathrm{~h}$ at optimum $\mathrm{pH}$ for kidney bean inhibitors to completely inhibit PPA (5) but over $6 \mathrm{~h}$ at $\mathrm{pH} 6.9$ for black kidney bean inhibitors to completely inhibit PPA (22). On the other hand, a Streptomyces inhibitor and PPA associated to form the complex within a few minutes (24). The ratio between the degrees of PPA inhibition by CBAI at two different levels suggests that a stoichiometric relationship is valid for their complex. This relationship was also 
Table 1. Inhibition of various amylases by CBAI.

\begin{tabular}{lc}
\hline Source of amylase & Inhibition $(\%)$ \\
\hline$\alpha$-Amylases & \\
Porcine pancreas & 100 \\
Human salivary & 100 \\
Barley malt & 0 \\
Aspergillus oryzae & 0 \\
Bacillis subtilis & 0 \\
$\beta$-Amylase & 0 \\
Sweet potato & \\
Amylase & 0 \\
Cranberry bean & \\
\hline
\end{tabular}

${ }^{\mathrm{a}}$ The extract from cranberry bean germinated for 7 days was used. Other enzymes were obtained from Sigma.

Table 2. Reactivity of CBAI with mammalian pancreatic $\alpha$-amylases.

\begin{tabular}{lcc}
\hline $\begin{array}{l}\text { Source of } \\
\text { pancreatic } \\
\alpha \text {-amylase }\end{array}$ & $\begin{array}{c}\text { Amount of CBAI (nM) } \\
\text { required for 50\% inhibition } \\
(\mathrm{pH} \mathrm{6.9)}\end{array}$ & $\begin{array}{c}\mathrm{pH} \mathrm{5.5)} \\
\text { Pig }\end{array}$ \\
Dog & 40 & 7.3 \\
Cat & 28 & 7.7 \\
Horse & 22 & 8.9 \\
Sheep & 30 & 8.0 \\
Cow & 250 & 6.7 \\
Rabbit & 3,000 & 100 \\
Guinea pig & 160 & 9.5 \\
Rat & 180 & 12 \\
Mouse & $>3,000$ & 27 \\
\hline
\end{tabular}

${ }^{a}$ Preparations from pancreatic acetone powder were used as amylases.

ascertained by using various concentrations of CBAI. As shown in Fig. 4, the residual activity of PPA decreased in inverse proportion to $\mathrm{CBAI}$ concentration and the molar ratio of CBAI to PPA to give a complete inhibition was obtained as $1: 1$ by extrapolation of the linear plot to the abscissa.

Table 1 summarizes the inhibitory effects of CBAI on amylases from various sources. The CBAI was as effective in inhibition against PPA as against human salivary $\alpha$-amylase, while it had no inhibitory effect on amylases from plant, fungus and bacteria.

Table 2 compares the concentrations of CBAI to yield $50 \%$ inhibition against 
pancreatic $\alpha$-amylases from mammals. Although mammalian pancreatic $\alpha$-amylases corresponding to one unit were used at either $\mathrm{pH}$, the concentration of CBAI to give $50 \%$ inhibition was much lower at $\mathrm{pH} 5.5$ than at $\mathrm{pH} 6.9$ for most of the enzymes. Under the physiological $\mathrm{pH}$ conditions, $\alpha$-amylases from pig, dog, cat, and horse were most effectively inhibited by CBAI, to which the enzymes from sheep, rabbit, guinea pig, and mouse followed. Noteworthily, the enzymes from cow and rat were little inhibited by CBAI even at a level of more than $3.0 \times 10^{-6} \mathrm{M}$ under the same conditions. There was a clear difference in optimum $\mathrm{pH}$ between the catalytic activity of pancreatic $\alpha$-amylase and the inhibitory activity of its inhibitor. The concentrations of CBAI to give $50 \%$ inhibition against pancreatic $\alpha$-amylases from cow and rat were $1.0 \times 10^{-7} \mathrm{M}$ and $2.7 \times 10^{-8} \mathrm{M}$, respectively, at $\mathrm{pH}$ optimal for the inhibitory activity, $\mathrm{pH}$ 5.5. The reactivity of inhibitor with amylase has been hitherto evaluated at $\mathrm{pH}$ optimal for the amylase activity (24-26). Probably for this reason, multi-forms of wheat $\alpha$-amylase inhibitors did not act on guinea pig pancreatic $\alpha$-amylase (25), nor did microbial inhibitors on rabbit pancreatic $\alpha$ amylase (24), nor did inhibitors from red gram, sorghum, pearl millet, sanwa millet and proso millet on horse pancreatic $\alpha$-amylase (26). Such inhibitors may also become more inhibitory against $\alpha$-amylases when assayed at weakly acidic $\mathrm{pH}$.

CBAI even at sufficiently high concentrations showed little inhibition against pancreatic $\alpha$-amylases from cow and rat at neutral $\mathrm{pH}$, suggesting that $\mathrm{CBAI}$ would not always serve as an inhibitor in the intestinal environments of these animals. In relation to this possibility, Savaiano et al. (27) reported that administration of red kidney bean $\alpha$-amylase inhibitor to rats did not affect their growth. On the contrary, Marshall and Lauda (5) described that human pancreatic $\alpha$-amylase was as much inhibited by white kidney bean $\alpha$-amylase inhibitor as PPA at pH 5.5. Layer et al. (28) have recently observed that perfusion of human duodenum with an aqueous solution containing kidney bean $\alpha$-amylase inhibitor leads to a considerable decrease in the amylase activity remaining in the lumen. This observation supports the possibility of use of $\alpha$-amylase inhibitor as an antidiabetic drug. Amylaseinhibitor interaction and physiological justification of the naturally occurring $\alpha$ amylase inhibitor remain further investigated.

\section{REFERENCES}

1) O'donnell, M. D., and McGeeney, K. F. (1976): Purification and properties of an $\alpha$ amylase inhibitor from wheat. Biochim. Biophys. Acta, 422, 159-169.

2) Granum, P. E. (1978): Purification and characterization of an $\alpha$-amylase inhibitor from rye (Secale cerale) flour. J. Food Biochem., 2, 103-120.

3) Shivaraj, B., and Pattabiraman, T. N. (1981): Natural plant enzyme inhibitors. Characterization of an unusual $\alpha$-amylase/trypsin inhibitor from ragi (Eleusine coracana Geartn.). Biochem. J., 193, 29-36.

4) Blanco-Labra, A., and Iturbe-Chinas, F. A. (1981): Purification and characterization of an $\alpha$-amylase inhibitor from maize (Zea maize). J. Food Biochem., 5, 1-17.

5) Marshall, J. J., and Lauda, C. M. (1975): Purification and properties of phaseolamin, an

Vol. 33, No. 5, 1987 
inhibitor of $\alpha$-amylase, from the kidney bean, Phaseolus vulgaris. J. Biol. Chem., 250, 8030-8037.

6) Powers, J. R., and Whitaker, J. R. (1977): Purification and some physical properties and chemical properties of red kidney bean (Phaseolus vulgaris) $\alpha$-amylase inhibitor. J. Food Biochem., 1, 217-238.

7) Irshad, M., and Sharma, C. B. (1981): Purification and properties of an $\alpha$-amylase protein-inhibitor from Arachis hypogaea seeds. Biochim. Biophys. Acta, 659, 326-333.

8) Frels, J. M., and Rupnow, J. H. (1985): Purification and partial characterization of two $\alpha$-amylase inhibitors from black bean (Phaseolus vulgaris). J. Food Biochem., 8, 281301.

9) Rao, M. N., Shurpalekar, K. S., and Sundaravalli, O. E. (1970): Purification and properties of an amylase inhibitor from colocasia (Colocasia esculenta) tubers. Ind. J. Biochem., 7, 241-243.

10) Sharma, K. K., and Pattabiraman, T. N. (1982): Natural plant enzyme inhibitors. Purification and properties of an amylase inhibitor from yam (Dioscorea alata). J. Sci. Food Agric., 33. 255-262.

11) Goto, A., Matsui, Y., Ohyama, K., Arai, M., and Murao, S. (1983): Purification and characterization of an $\alpha$-amylase inhibitor (Haim) produced by Streptomyces griseosporeus YM-25. Agric. Biol. Chem., 47, 83-88.

12) Plus, W., and Keup, U. (1973): Influence of an $\alpha$-amylase inhibitor (BAY d 7791) on blood glucose, serum insulin and NEFA in starch loading tests in rats, dog and man. Diabetologia, 9, 97-101.

13) Goto. A., Arai, M., and Murao, S. (1985): Application of the proteinaceous $\alpha$-amylase inhibitor Haim to horse and carp $\alpha$-amylase purification and some properties of the purified $\alpha$-amylase. Nippon Nogeikagaku Kaishi (J. Agric. Chem. Soc. Jpn.), 59, 411417.

14) Kotaru, M., Saito, K., Yoshikawa, H., Ikeuchi, T., and Ibuki, F. (1987): Purification and some properties of an $\alpha$-amylase inhibitor from cranberry bean (Phaseolus vulgaris). Agric. Biol. Chem., 51, 577-578.

15) Tsujisaka, Y. (1975): Purification of amylase, in Affinity Chromatography (in Japanese), ed. by Yamazaki, M., Ishii, S., and Iwai, K., Kodansha, Tokyo, pp. 41-50.

16) Lowry, O. H., Rosebrough, N. J., Farr, A. L., and Randall, R. J. (1951): Protein measurement with the Folin phenol reagent. J. Biol. Chem., 193, 265-275.

17) Sakano, Y., Takahashi, S., and Kobayashi, T. (1983): Purification and properties of two active components from crystalline preparation of porcine pancreatic $\alpha$-amylase. Dempun Kagaku (J. Jpn. Soc. Starch Sci.), 30, 30-37.

18) Murao, S., Goto, A., Matsui, Y., Ohyama, K., and Arai, M. (1981): Isolation and identification of a hog pancreatic $\alpha$-amylase inhibitor (Haim) producing Streptomyces. Agric. Biol. Chem., 45, 2599-2604.

19) Powers, J. R., and Whitaker, J. R. (1977): Effect of several experimental parameters on combination of red kidney bean (Phaseolus vulgaris) $\alpha$-amylase inhibitor with porcine pancreatic $\alpha$-amylase. J. Food Biochem., 1, 239-260.

20) Buonocore, V., Giardina, P., Parlamenti, R., Poerio, E., and Silano, V. (1984): Characterisation of chicken pancreas $\alpha$-amylase isoenzymes and interaction with protein inhibitors from wheat kernel. J. Sci. Food Agric., 35, 225-232.

21) Kotaru, M., Yoshikawa, H., Ikeuchi, T., Saito, K., and Ibuki, F. (1986): Properties of cranberry bean $\alpha$-amylase inhibitor. Proc. Annual Meeting of Agric. Chem. Soc. Jpn., Kyoto, p. 654. 
22) Frels, J. M., and Rupnow, J. N. (1985): Characterization of two $\alpha$-amylase inhibitors from black bean (Phaseolus vulgaris). J. Food Sci., 50, 72-77.

23) Tanizaki, M. M., and Lajolo, F. M. (1985): Kinetics of the interaction of pancreatic $\alpha$ amylase with a kidney bean (Phaseolus vulgaris)-amylase inhibitor. J. Food Biochem., 9, 71-90.

24) Arai, M., Oouchi, N., and Murao, S. (1985): Inhibitory properties of an amylase inhibitor, Paim, from Streptomyces corchorushii. Agric. Biol. Chem., 49, 987-991.

25) Buonocore, V., Petrucci, T., and Silano, V. (1977): Wheat protein inhibitors of $\alpha$ amylase. Phytochemistry, 16, 811-820.

26) Kutty, A. V. M., and Pattabiraman, T. N. (1986): Specificity of plant amylase inhibitors on ten pancreatic alpha amylases. J. Food Biochem., 10, 117-124.

27) Savaiano, D. A., Powers, J. R., Costello, M. J., Whitaker, J. R., and Clifford, A. J. (1977): The effect of an $\alpha$-amylase inhibitor on the growth rate of weanling rats. Nutr. Rep. Int., 15, 443-449.

28) Layer, P., Carlson, G. L., and Dimagno, E. P. (1985): Partially purified white bean amylase inhibitor reduces starch digestion in vitro and inactivates intraduodenal amylase in humans. Gastroenterology, 88, 1895-1902. 